\title{
Çorum Alaca Havzasında Toprak Erozyon Duyarlılık Faktörünün Farklı Enterpolasyon Modeller Kullanılarak Konumsal Dağılımlarının Belirlenmesi
}

\author{
Ali İMAMĞLU' Muhammed BAHADIR' Mrhan DENGiZ²* \\ 'Ondokuz Mayıs Üniversitesi, Fen Edebiyat Fakültesi, Coğrafya Bölümü, Samsun \\ ${ }^{2}$ Ondokuz Mayıs Üniversitesi, Ziraat Fakültesi, Toprak Bilimi ve Bitki Besleme Bölümü, Samsun
}

\begin{abstract}
*Sorumlu yazar e-posta (Corresponding author e-mail) : odengiz@omu.edu.tr
Geliș tarihi (Received) : 13.01.2016

Kabul tarihi (Accepted) : 10.05.2016
\end{abstract}

\section{Öz}

Ülkemizin birçok bölgesinde iklim, topografik koșullar, yanlıș arazi kullanımları gibi birçok olumsuz faktörlerin etkisiyle verimli toprak katmanlarının tașınması sonucu, toprağın üretkenliğinin azalmasına neden olan en önemli arazi problemlerinden biri toprak erozyonudur. Calıșmanın amacı, havza topraklarının erozyon duyarlıık faktörü belirlenerek, farklı enterpolasyon modeller kullanarak konumsal dağılımının belirlenmesi ve haritalanmasıdır. Çalıșma İç Anadolu Bölgesi'nin Orta Kızılırmak Bölümü'nün kuzey kısımlarında yer alan Çorum Alaca Havzasında gerçekleștirilmiștir. Toplam çalıșma alanı 1656,4km²' dir. Araștırma sahası 825 m ile 1726 m arasında değișen düz, engebeli ve dağlık alanlardan olușan farklı topoğrafik yapılardan olușmaktadır. Çalıșma alanında grid yöntemine göre her 2,5 x 2,5 km aralıklarla toplam 312 yüzey $(0-20 \mathrm{~cm})$ toprak örneği alınmıștır. Toprakların bazı fiziko kimyasal özellikleri belirlenmiș ve $\mathrm{K}$ faktör eșitliği kullanılarak her bir noktaya ait toprak erodibilite değerleri hesaplanmıștır. Belirlenen her bir örnekleme noktasına ait erodibilite değeri, alana en uygun jeoistatistik model ile erodibilite dağılım haritası üretilmiștir. Çalıșma alanının \% 57,8' inde toprakların az așınabilir, \% 42, 1'inde ise orta derece așınabilir olduğu belirlenmiștir.

Anahtar Kelimeler: Çorum-Alaca Havzası, K-faktörü, jeoistatistik, toprak așınabilirliği

\section{Determination of Spatial Distribution Pattern of Soil Erodibility Factor Using Different Interpolation Models in Corum-Alaca Watershed}

\begin{abstract}
Soil erosion is one of the most important soil degradation problems almost in all parts of Turkey. Undesirable climate and topographic conditions as well as in appropriate land uses cause severe erosion that reduces soil productivity by removing fertile topsoil layers. The objective of this research was to determine and map spatial distribution of soil erodibility using different interpolation models. This research was carried out in Çorum Alaca watershed located at north part of the Central Kızlırmak Region in the Central Anatolia. Total study area covers about $1656.4 \mathrm{~km}^{2}$ with different topographic features and the altitude changes from $825 \mathrm{~m}$ to $1726 \mathrm{~m}$. In total 312 surface soil samples from 0-20
\end{abstract}


$\mathrm{cm}$ depth were collected at the intersections of a $2.5 \times 2.5 \mathrm{~km}$ grid system. Some physicochemical properties were determined and soil erodibility factor was calculated. Soil erodibility distribution map was produced using the best fit geoistatistik model for erodibility values of each selected sampling point. The results indicated that $57.8 \%$ of the study area has low erodobility and $42.1 \%$ moderate erodobility.

Key Words: Çorum-Alaca watershed, K-factor, jeostatistic, soil erodibility

\section{Giriș}

En geniș anlamılla erozyon yeryüzünün akarsu, rüzgar, buzul, dalga ve biyolojik sebepler gibi dıș etmenlerle așındırıması ve tașınması olayıdır. Coğrafya bilimi için erozyon topoğrafyanın olușumunda doğrudan etkili bir etmen ve süreç olmasının yanı sıra, ülkemiz gibi topografik değișkenliği çok fazla olan alanlarda topografya, erozyon olușumu ve süreçleri üzerine önemli etki yapmaktadır. Toprak așınımı, erozyonun doğal bir parçası olsa da, doğal kaynakların sürdürülebilirliğini tehdit etmesi açısından önemli bir sorun olarak ortaya çıkmaktadır.

Ülkemizdeki erozyon tehlikesinin boyutunun fazla olduğu ve uygulamaya yönelik her türlü bilimsel ve teknik koruma önlemleri alınmazsa, tehlike boyutlarının giderek artacağı ve özellikle toprak, topografya, su ve bitki örtüsü açısından geri-dönüșümsüz evrelere gelinebileceği açık bir șekilde bilinmektedir (Erpul ve Deviren Saygın, 2012).

Toprak erozyonu konusunda pek çok araștırmalar yapılmıș ve yöntemler geliștirilmiștir. Erozyonun nedenleri bilinmekle beraber nedensel etmenlerin ölçülmesi, etkileme koșulları, etmenler arasındaki etkileșimin sonuca yansıma ağırlığı, derecesi ve sayısal değerini saptamak hayli karmașıktır. Bu durumları dikkate alan araștırmacılar son 50-60 yıl içerisinde birikmiș olan bulgu ve bilgileri de değerlendirerek, belli koșullar ve etmenler bilindiği takdirde toprak erozyonunun miktarını tahmin etme ve hesaplama yolunda önemli bir noktaya ulașmıșlardır (Parlak vd., 2014). Bu yöntemlerden Wischemeier ve Smith (1978) tarafından geliștirilip, A.B.D. Toprak Koruma teșkilatı tarafından adapte edilen "Evrensel Toprak Kaybı Eșitliği" (USLE) isimli matematik model son yıllarda erozyonun tahmininde kullanılan en bașta gelen bir yöntem haline gelmiștir. 1957 yılında ortaya atılmıș bulunan bu yöntem ilk önceleri

sadece tarım alanlarında kullanılmıș, 1971' de inșaat yapılan alanlara uygulanmıș ve 1972' den beri de orman ve mera alanları için de kullanılır hale gelmiștir (Balcı, 1996). Auerswald (1986), Almanya'nın Bavyera eyaletinin güneyindeki devlete ait arazilerin erozyona duyarlıık sınırlarının belirlenmesi amaciyla 343 toprak örneğinin toprak așınım (K) faktörünü hesaplamıștır. Yaptığı hesaplama sonuçlarına göre, haritalama birimindeki hatalara ve daha geniș alanlardaki tahminler için sınırlı olmasına rağmen toprakların $\mathrm{K}$ faktörlerinin tahmini için uygun olacağını belirtmiștir. Aynı araștırmada lös ana materyalli toprakların $\mathrm{K}$ faktörü yaklașık 0.09 bulunmuș olup; bünye karșılaștırmasında alüvyal topraklardan daha yüksek çıkarken kumlu topraklar için 0,003 bulunmuștur. Bașkan ve Dengiz (2008), Ankara'nın Soğulca Havzasında geleneksel ve jeoistatistik yöntemlerle hazırladıkları toprağın așınabilirlik (K faktörü) haritasının daha doğru tahminler verdiğini saptamıșlardır.

Bu çalıșmanın amacı; Çorum Alaca Havzasında dağılıș gösteren farklı toprakların așınabilirlik faktörlerinin belirlenmesi ve farklı enterpolasyon modelleri kullanmak suretiyle, havzanın erozyon duyarlılık sınıflarının konumsal dağıım haritasının olușturulmasıdır.

\section{MATERYAL VE YÖNTEM}

Çalıșma alanı İç Anadolu Bölgesi'nin Orta Kızııırmak Bölümü'nün kuzey kısımlarında bulunmaktadır. Araștırma sahası Alaca havzasının tamamından olușmaktadır. Havzanın idari sınırlarına bakıldığında, güney ve güneydoğudan Yozgat'ın Sorgun ilçesi, güneybatıdan ise Sungurlu sınırlarına girmektedir (Șekil 1).

Çalıșma alanının toplam alanı 1656,4 km²'dir. Araștırma sahasının güney kesimleri Bozok platosunun kuzeyidir. Yeșilırmak'ın su toplama havzasında bulunan havza Kızıırmak havzası ile sınır 


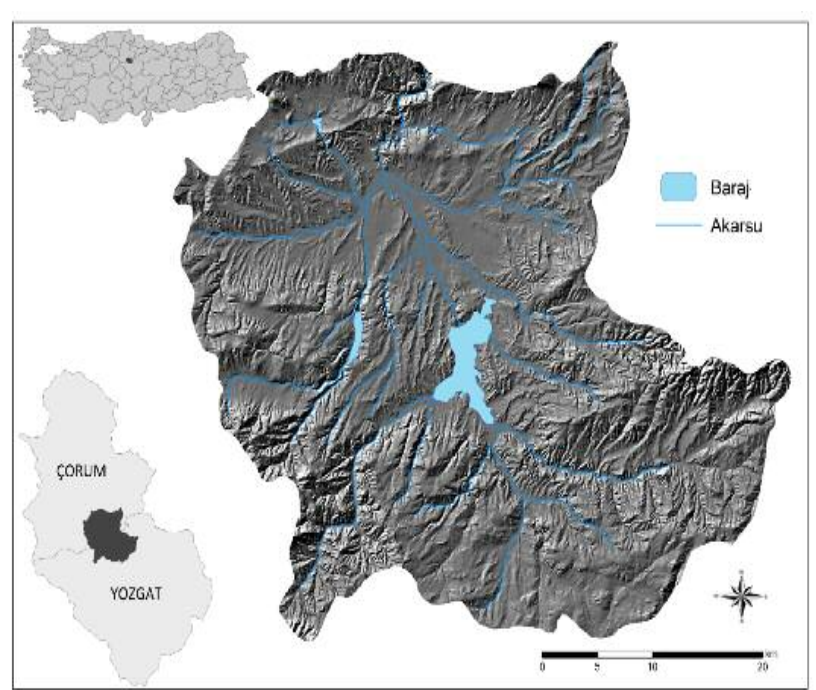

Șekil 1. Araștırma alanı lokasyon haritası.

Figure 1. Location map of the study area

olușturmaktadır. Sahanın suyunu Alaca Çayı toplamakta ve bu akarsu araștırma sahasından çıkınca Çorum Çayı'na katılmakta Çorum Çayı' da Çekerek Irmağı ile birleșmektedir. Alaca meteorolojik istasyonun verilerine göre yıllık yağıș miktarı 364,8 mm, en çok yağıșın ise Nisan (46,5 mm) ve Mayıs (54, 1 mm) aylarında düștüğü görülmektedir. Alanın yıllık sıcaklık ortalaması ise 9,5 ${ }^{\circ} C^{\prime}$ dir. En soğuk ay Ocak $\left(-1,8^{\circ} \mathrm{C}\right)$, en sıcak ay Temmuz ve Ağustos aylarıdır $\left(20,1^{\circ} \mathrm{C}\right)$ (Çizelge 1$)$.

Havza topraklarının erozyona olan duyarlııklarının belirlenmesinde kullanılan indeks hesaplanması ve alan içerisinde bu indekslerin dağılımlarının belirlenmesi amacıyla ArcGIS 10.2v jeoistatistiksel modelleriden yararlanımıștır. Bu amaçla alandan grid yöntemine göre her 2500 m aralıklarla toplam 312 yüzey $(0-20 \mathrm{~cm}$ ) toprak örneği alınmıștır (Șekil 2).

Toprak örnekleri havada kurutularak 2 mm'lik elekten elenmiștir. Toprak örneklerinde; bünye (Bouyoucous, 1951 ), hacim ağırlığı (Blake ve Hartge, 1986), hidrolik iletkenlik (Klute ve Dirksen, 1986), kireç (Soil Survey Staff, 1993), toprak reaksiyonu (pH) (Soil Survey Staff, 1992), elektriksel iletkenlik (Soil Survey Staff, 1992), organik madde ( Walkley-Black

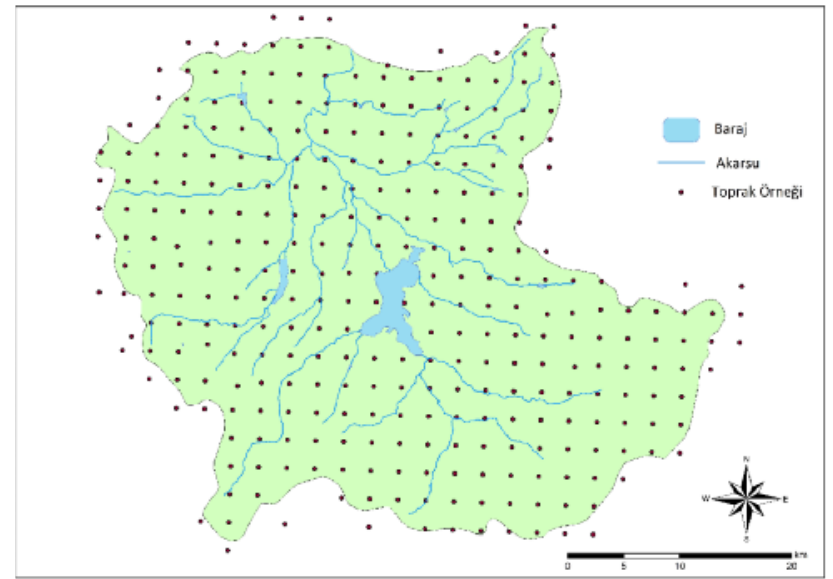

Şekil 2. Araștırma alanı toprak örnekleme noktaları

Figure 2. Soil samples points of the study area

yönteminin Jackson (1958) tarafından modifiye edilmiș șekli) analizleri yapıımıștır.

Analizler sonucunda elde edilen değerler, Wischmeier ve Smith (1978) tarafından belirtilen așağıda verilen formülde (eșitlik 1 ) ile yerine yerleștirilerek, toprak örneği alınan her bir noktanın $\mathrm{K}$ değeri elde edilmiștir.

$K=\frac{1}{100}\left\{2.1 \times 10^{-4} \times(12-O M) \times[S I \times(S A+S I)]^{.14}+2.5 \times(P E-3)+3.25 \times(S T-2)\right\}$

K= Toprağın erozyona duyarlılık faktörü

$\mathrm{OM}=\%$ Organik madde

SI= Silt içeriği,

$\mathrm{SA}=$ Kum içeriği,

$P E=$ Hidrolik iletkenlik,

ST= Strüktür sınıfı.

Bu eșitlikte toprak organik madde miktarı \% 4'ten büyükse \% 4 olarak kabul edilmektedir (Renard vd., 1997). K sınıf değerleri Çizelge 2 'de verilmiștir.

Araștırma sahasından alınan 312 toprak örneğinde 10 farklı fiziksel ve kimyasal özellikler incelenmiș ve bu özelliklerin tanımlayıc istatistiksel hesaplamaları yapılmıștır. Toprakların bünye, hacim ağırlığı, hidrolik iletkenlik, kireç, pH, elektriksel iletkenlik ve organik madde gibi bazı fiziko-kimyasal

Çizelge 1 . Alaca meteoroloji istasyonu aylık ortalama yağıș ve sıcaklık değerleri (mm, $\left.{ }^{\circ} \mathrm{C}\right)$.

Table 1 . Average monthly rainfall and temperature values of Alaca weather station $\left(\mathrm{mm},{ }^{\circ} \mathrm{C}\right)$.

\begin{tabular}{|c|c|c|c|c|c|c|c|c|c|c|c|c|c|}
\hline Çorum & & & & & & & ylar & & & & & & \\
\hline Alaca & $\mathrm{O}$ & S & $\mathrm{M}$ & $\mathrm{N}$ & $\mathrm{M}$ & $\mathrm{H}$ & $\mathrm{T}$ & A & E & E & $\mathrm{K}$ & A & Yıllık \\
\hline $\begin{array}{l}\text { Yağıș, } \\
\text { mm }\end{array}$ & 32,4 & 26,3 & 33,6 & 46,5 & 54,1 & 37,6 & 11,6 & 12,1 & 15,1 & 25,4 & 34 & 36,1 & 364,8 \\
\hline $\begin{array}{l}\text { Sicaklık, } \\
{ }^{\circ} \mathrm{C}\end{array}$ & $-1,8$ & $-0,7$ & 4,1 & 9,4 & 13,6 & 17,4 & 20,1 & 20,1 & 16 & 10,8 & 4,7 & 0,4 & 9,5 \\
\hline
\end{tabular}


Çizelge 2. K Sınıf Değeri (Wishmeier ve Simith, 1978)

Table 2. K values classes of soil

\begin{tabular}{ccc}
\hline Sınıf & Tanımlama & Değer \\
\hline 1 & Çok Az Așınabilir & $0,00-0,05$ \\
2 & Az Așınabilir & $0,05-0,10$ \\
3 & Orta Derece Așınabilir & $0,10-0,20$ \\
4 & Yüksek Așınabilir & $0,20-0,40$ \\
5 & Çok Yüksek Așınabilir & $0,40-0,60$ \\
\hline
\end{tabular}

Özellikleri arasındaki ilișkiler Spearman korelasyonu kullanılarak analiz edilmiș bu analizlerin yapılmasında SPSS 17.0 paket programı kullanılmıștır.

Toprakların $\mathrm{K}$ faktörü sınıflarının alansal dağılımının belirlenmesinde, en çok kullanılan enterpolasyon yöntemlerinden IDW, RBF (Spline) deterministik yöntemler ile stokastik yöntemlerden de (temelde Kriging olarak da bilinmektedir) doğal (ordinary), evrensel (universal), basit (simple) kriging yöntemleri kullanılmıștır. Yöntemlerin karșılaștırılmalarında ölçülen değerler ve tahmin edilen değerler arasındaki ilișkiyi sorgulayabilmek, ölçülen değerlere en yakın sonucu veren bașka bir ifade ile yöntemler arasından en uygun olanının seçebilmek için literatürde farklı karșılaștırma yöntemlerinin dikkate alındığı görülmektedir. Genel anlamda en yaygın kullanılan yöntemler; karesel ortalama hata (RMSE), ortalama mutlak hata (MAE), yöntemlerdir. Bu çalıșma için RMSE seçilmiș ve jeoistatistiksel çözümde kullanılan 5 yöntem karșılaștırılmıștır. En düșük RMSE değerini veren yöntem, en uygun yöntem olarak değerlendirilmiștir. RMSE'nin hesaplanmasında așağıdaki formül (eșitlik 2) kullanılmıștır.

$R M S E=\sqrt{\frac{\sum\left(z_{i^{*}}-z_{i}\right)^{2}}{n}}$

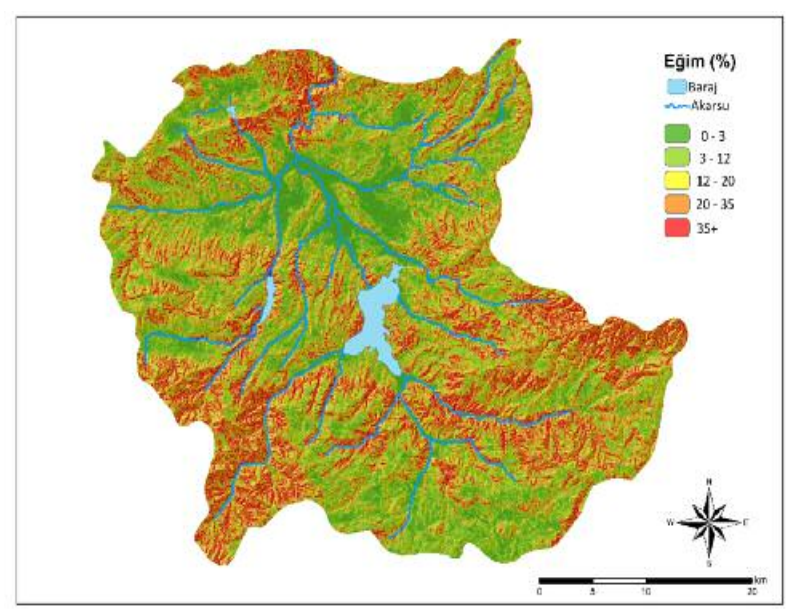

$Z_{i}$ : tahmin edilen değer, $Z_{i *}$ ölçülen değer ve örnek sayısını ifade etmektedir.

\section{BULGULAR VE TARTIȘMA}

\section{Çalıșma Alanın Genel Topografik Özellikleri, Arazi Kullanımı ve Arazi Örtüsü}

Çalıșma alanına ait farklı topoğrafik özelliklerin çıkartılmasına yönelik 1:25.000 ölçekli topoğrafik harita CBS ortamında sayısallaștırılarak alana ait sayısal eș yükselti, yükselti, eğim haritaları olușturulmuștur (Șekil 3). Araștırma sahası 825 m ile 1726 m arasında değișen düz, engebeli ve dağlık alanlardan olușan farklı topoğrafik yapılardan olușmaktadır.

Araștırma sahası eğim haritasına bakıldığında, sahanın özellikle güney ve doğu kesimlerinin daha eğimli olduğu görülmektedir. Havzada genellikle yükseltisi arttıkça topoğrafyanın eğimide artmaktadır. Güneybatıda Akçadağ ve çevresi, doğuda Toprakdede Tepesi ve çevresi, kuzeyde ise Çorum depresyonu ile Alaca depresyonunu birbirinden ayıran Büyükcamili ve İbrahim köyü yerleșmelerinin bulunduğu sahalar çalıșma alanında en fazla eğimin olduğu yerlerdir. İbrahim köyünden güneybatı yönlü devam eden Ezinepazar fayı boyunca eğimli sahalar görülmektedir. Bu sahaların yanında özellikle Seyitnizam, Büyüköz, Eymir, Kırımözü dereleri vadilerinde eğim değerleri oldukça yüksektir. Araștırma sahasında yüzeylenen bazı formasyonların dirençsiz ve gevșek yapıda olması vadilerin derine yarılmasına ve kısa mesafede yükselti farkına bağlı eğim değerlerinin yüksek olmasına sebep olmaktadır. Araștırma sahasının genel eğimine baktığımızda sahanın yaklașık \% 70'inin \% 3'ün üzeri eğimli, yaklașı \% 30'unun ise düz ve düze yakın alanlardan oluștuğu görülmektedir (Çizelge 3).

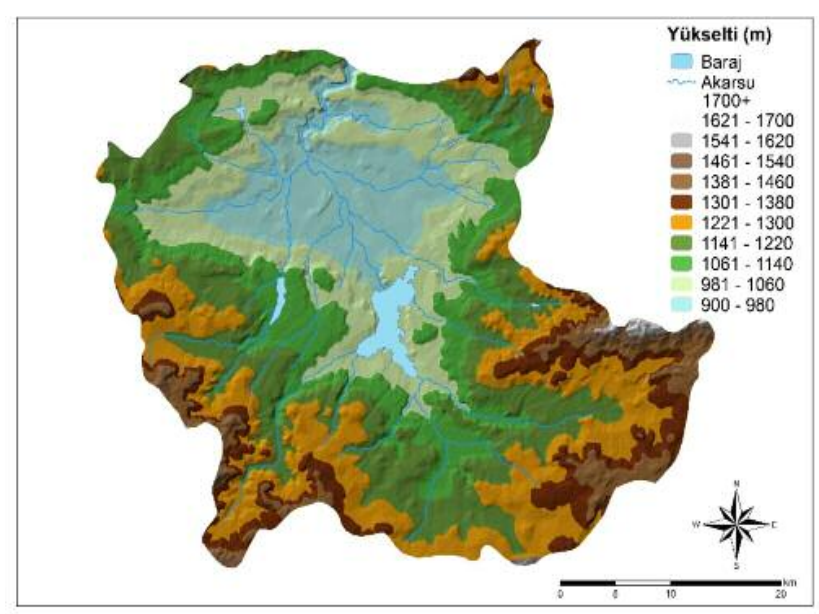

Sekil 3. Araștırma alanına ait eğim ve yükseklik dağıım haritaları

Figure 3. Slope and elevation distribition maps of the study area 
Çizelge 3. Araștırma alanı eğim sınıflarının alansal ve oransal dağııımı

Table 3. Spatial and proportional distribution of the study area slope classes

\begin{tabular}{ccc}
\hline Eğim Sınıfı (\%) & Alan $\left(\mathrm{km}^{2}\right)$ & Oran $(\%)$ \\
\hline $0-3$ & 466,85 & 28,2 \\
$3-12$ & 874,01 & 52,8 \\
$12-20$ & 240,88 & 14,5 \\
$20-35$ & 73,67 & 4,4 \\
$35+$ & 0,99 & 0,1 \\
Toplam & 1656,4 & 100,0 \\
\hline
\end{tabular}

Araștırma sahasında arazi kullanımı ve arazi örtü dağıııı bakımından incelendiğinde meșelik alanlar, mera sahaları, dağlık alanlar, bağ bahçe, çıplak kayalık, sulu ve kuru tarım alanları bulunmaktadır (Șekil 4). Hakim arazi kullanımı ise kuru tarımdır.

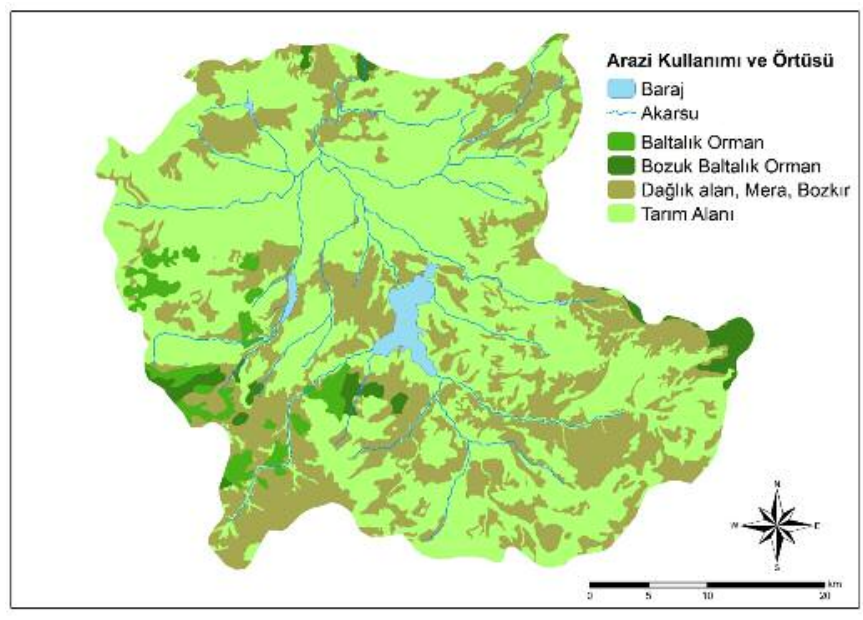

Șekil 4. Araștırma alanı arazi kullanımı ve arazi örtü haritası

Figure 4. Land use and land cover map of the study area

\section{Toprak Özelliklerine Ait Tanımsal İstatistikler}

Araștırma sahasından toplam 312 adet yüzey (0$20 \mathrm{~cm})$ toprak örneği alınmıștır. Bu noktalardan alınan toprak örneklerinde yöntemde belirtilen analizler yapılmıștır. Duyarlılık indeksine ait haritalarının olușturulmasının nedeni, özellikle farklı arazi kullanımı ve arazi örtüsü altında, havzadaki farklı topoğrafyalarda meydana gelen toprak özellikleri ve kayıplarının değișkenlik göstermesidir. Bu amaçla, önce toprak özelliklerinin tanımlayıcı istatistikleri hesaplanarak normal dağılıma uygunlukları Kolmogorov-Smirnov testi SPSS (Karaatlı, 2010) ile kontrol edilmiștir. Araștırma sahasından alınan toprak örneklerinin bazı fiziksel ve kimyasal analiz sonuçlarına ait tanımlayıcı istatistikleri Çizelge 4' de verilmisțir. Havza topraklarında, kum miktarı \%
16,04-93,06, kil miktarı \% 2,74-62,82 ve silt miktarı ise \% 3,55-37,33 arasında değișmekte olup, hâkim bünye sınıfı kil, killi tın ve kumlu killi tındır. Toprakların tane büyüklüğü dağıımları incelendiğinde kil ve silt içeriğinin normal dağlımlar sergilediği, kum içeriğinin ise sağa çarpık bir dağlım sergilediği görülmektedir. En düșük $(6,80)$ ve en yüksek $(8,62)$ değerlere göre, nötr ve kuvvetli alkalin reaksiyon arasında değișen toprak pH'sının sola çarpık dağılım gösterdiği görülmektedir. Havza topraklarının \% 89,1 hafif alkalin özellik göstermektedir.

Araștırma topraklarının EC değerleri 0,03-0,99 dS $\mathrm{m}^{-1}$ arasında değișmektedir. Ayrıca değișkenlik katsayısı çok yüksek olan EC değerleri sağa çarpık bir dağılım göstermektedir. Değișkenlik katsayısı yüksek olan çok düșük ve çok yüksek kireçli özellikler gösteren kireç miktarının sağa çarpık bir dağılım gösterdiği görülmüștür. Havza topraklarında kireç miktarı 0 ile 48,53 arasında değișkenlik gösterirken, toprakların \% 45, 5'i orta kireçli sınıfına girmektedir. Yüksek değișebilirlik gösteren organik madde miktarının 0,21 ile 6,62 arasında değerler gösterdiği görülmüștür. Havza topraklarının \% 34,6'sının az, \% 31,4'ünün orta derecede organik madde içerdiği görülmüștür. Değișkenlik katsayısı yüksek olan hidrolik iletkenliğin sağa çarpık dağılım sergilediği ve 0,02-15,59 (cm h-1) arasında değișmektedir. Havza topraklarının hidrolik iletkenliğinin yüzde oranına baktığımızda ise $\% 47,4$ 'ünün çok yavaș, $\%$ 16,7 'sinin yavaș, \% 24,7'sinin yavaș ile orta, \% 8,3'ünün orta, \% 2,2'sinin orta hızlı ve \% 0,6'sının hızlı iletkenlik özelliği gösterdiği görülmektedir. Innceleme alanı topraklarının hacim ağırlığı normal dağılım sergilemektedir. 1,27 ile 1,60 g cm değerleri arasında değișen hacim ağırlıklarının \% 833 'ünün 1,32 ile $1,52 \mathrm{~g} \mathrm{~cm}^{3}$ arasında değiștiği görülmektedir.

Araștırma sahası topraklarının K faktörünün sola çarpık bir dağılım gösterdiği görülmüștür. En düșük $(0,01)$ ve en yüksek $(0,14)$ değerlere göre çok az așınabilir ve orta derece așınabilir değerler gösteren K faktörünün \% 50'sinin az așınabilir sınıfına girerken, \% 38,8'inin ise orta derece așınabilir sınıfına girdiği görülmektedir. Toprak fiziko-kimyasal özelliklerine ilișkin çarpıklık katsayıları incelendiğinde, normal dağılımdan en uzak değer gösteren toprak özelliğinin hidrolik iletkenlik olduğu, en yakın değer gösteren toprak özelliğinin ise K faktörü özelliği olduğu görülmüștür.

Ayrıca toprakların fiziko-kimyasal özellikleri 
Çizelge 4. Araștırma alanı toprak analiz sonuçlarının tanımlayıcı istatistikleri

Table 4. Descriptive statistics of soil analysis results of the study area

\begin{tabular}{|c|c|c|c|c|c|c|c|c|c|c|}
\hline \multirow{2}{*}{$\begin{array}{l}\text { Tanımlayıcı } \\
\text { İstatistik } \\
\text { Parametreleri }\end{array}$} & \multicolumn{3}{|c|}{ Bünye \% } & \multirow[b]{2}{*}{$\mathrm{pH}$} & \multirow[b]{2}{*}{$\begin{array}{c}\text { EC } \\
\mathrm{dS} \mathrm{m}^{-1}\end{array}$} & \multirow[b]{2}{*}{$\begin{array}{c}\mathrm{CaCO}_{3} \\
\%\end{array}$} & \multirow[b]{2}{*}{$\begin{array}{c}\mathrm{OM} \\
\%\end{array}$} & \multirow[b]{2}{*}{$\begin{array}{c}\mathrm{HI} \\
\mathrm{cm} / \mathrm{h}\end{array}$} & \multirow[b]{2}{*}{$\begin{array}{c}\mathrm{HA} \\
\mathrm{g} / \mathrm{cm}^{3}\end{array}$} & \multirow[b]{2}{*}{ K } \\
\hline & Kil & Silt & Kum & & & & & & & \\
\hline Ortalama & 36,50 & 19,99 & 43,51 & 8,11 & 0,22 & 10,29 & 2,42 & 0,98 & 1,42 & 0,09 \\
\hline Standart Sapma & 13,28 & 5,53 & 14,71 & 0,32 & 0,11 & 8,36 & 1,17 & 1,93 & 0,07 & 0,02 \\
\hline *Değișkenlik Katsayısı & 36,38 & 27,66 & 33,82 & 4,04 & 51,52 & 81,24 & 48,37 & 196,53 & 5,20 & 29,16 \\
\hline Varyans (Örnek) & 176,36 & 30,60 & 216,65 & 0,10 & 0,01 & 69,97 & 1,37 & 3,72 & 0,01 & 0,01 \\
\hline En Düșük Değer & 2,74 & 3,55 & 16,04 & 6,80 & 0,03 & 0,00 & 0,21 & 0,02 & 1,27 & 0,01 \\
\hline En Yüksek Değer & 62,82 & 37,33 & 93,06 & 8,62 & 0,99 & 48,53 & 6,62 & 15,59 & 1,60 & 0,14 \\
\hline **Çarpıklık & $-0,43$ & 0,05 & 1,02 & $-1,62$ & 1,98 & 1,34 & 0,88 & 4,05 & 0,25 & $-0,68$ \\
\hline Basıklık & $-0,51$ & 0,83 & 0,85 & 3,87 & 7,62 & 2,74 & 0,69 & 20,65 & $-0,68$ & 0,02 \\
\hline n (Örnek sayısı) & 312 & 312 & 312 & 312 & 312 & 312 & 312 & 312 & 312 & 306 \\
\hline
\end{tabular}

*Değișkenlik Katsayısı: < 15= Düșük Değișkenlik 15-35= Orta Değișkenlik >35 = Yüksek Değișkenlik **Çarpıklık: < |† $0.5 \mid=$ Normal Dağıım 0,5-1,0 = Veri setine karakter dönüșümü uygulanır

ÇK > 1,0 $\rightarrow$ Logaritma dönüșümü uygulanır

arasındaki ilișkiler Spearman korelasyonu kullanılarak analiz edilmiș ve önemli korelasyonlar elde edilmiștir (Çizelge 5). Korelasyon analizi sonuçlarına göre 55 korelasyon çiftinden 37 adedi istatistiksel olarak anlamlı $(p<0,05 ; \quad p<0,01)$ bulunmuștur. $\mathrm{K}$ faktörünün ise $\mathrm{pH}$ ile aralarında herhangi bir ilișki bulunamamıș, kil, silt, EC, kireç, organik madde ile arasında \% 1 düzeyinde önemli pozitif bir ilișki olduğu; kum, hidrolik iletkenlik ve hacim ağılığı ile de arasında negatif bir korelasyon ilișkisi olduğu görülmüștür. Büyüköztürk (2009), korelasyon katsayısının 1,00 ile 0,70 arasında olmasını yüksek, 0,69 ile 0,30 arasında olmasını orta ve 0,29'un altında olmasını ise düșük düzeyde ilișki olduğu șeklinde sınıflandırmaktadır. Buna göre en yüksek pozitif korelasyon ilișkisi kum ile hidrolik iletkenlik arasında $\left(0,84^{* *}\right)$ görülürken, en yüksek negatif korelasyon ilișkisi ise kil ile hidrolik iletkenlik arasında $\left(-0,96^{* *}\right)$ bulunmuștur.

\section{Enterpolasyon Modeller ve K Dağılımı}

Çorum Alaca havzası toprak așınabilirlik indeksinin (K faktörü) alansal analizi kapsamında 14 farklı enterpolasyon yöntemi kullanılmıștır. Hangi dağılımın en doğru olduğunun belirlenmesi amacıyla her bir yöntemin RMSE değeri belirlenmiștir. Yöntemlere ait RMSE değerleri Çizelge 6'da verilmiștir.

En küçük RMSE değerini $(0,0284)$ veren yöntemin simple kriging'ge ait spherical model olduğu belirlenmiștir. Simple kriging'ge ait spherical model kullanılarak araziden alınan toprak örnekleri için, her bir noktaya yönelik olarak belirlenen $\mathrm{K}$ değerlerinin alansal dağılımı Çizelge 7' de verilmiș ve dağılımı gösteren harita Șekil 5'de gösterilmiștir. Çizelge 7'den anlașılacağı üzere alanın yarıdan fazlası az așınabilir özellik gösterirken, $\% 42,1^{\prime}$ i ise orta derecede așınabilir sınıfta belirlenmiștir.

Çizelge 5. Araștırma alanı toprak analiz sonuçlarının faktör analizi (Spearman Korelasyonu)

Table 5. Factor analysis of soil analysis results of the study area(Spearman Correlation)

\begin{tabular}{|c|c|c|c|c|c|c|c|c|c|c|}
\hline & Nem & Kil & Silt & Kum & $\mathrm{pH}$ & $E C$ & $\mathrm{CaCO}_{3}$ & OM & $\mathrm{HI}$ & $\mathrm{HA}$ \\
\hline Kil & $0,66^{*}$ & & & & & & & & & \\
\hline Silt & 0,08 & $-0,08$ & & & & & & & & \\
\hline Kum & $-0,66^{*}$ & ${ }^{*}-0,92^{*}$ & ${ }^{*}-0,24^{*}$ & & & & & & & \\
\hline $\mathrm{pH}$ & 0,01 & $-0,05$ & $-0,05$ & 0,03 & & & & & & \\
\hline EC & 0,41 * & ${ }^{*} 0,45$ * & 0,09 & $-0,43^{*}$ & ${ }^{*}-0,36^{*}$ & & & & & \\
\hline $\mathrm{CaCO}_{3}$ & 0,21 * & * 0,32 * & ${ }^{*} 0,20$ * & * $-0,36^{*}$ & *0,09 & $0,25^{*}$ & & & & \\
\hline $\mathrm{OM}$ & 0,06 & 0,12 * & 0,05 & $-0,08$ & $-0,08$ & $0,27^{*}$ & ${ }^{* *} 0,07$ & & & \\
\hline Hi & $-0,62^{*}$ & ${ }^{*}-0,96 *$ & ${ }^{*} 0,13$ * & 0,84 * & *0,05 & $-0,40^{*}$ & ${ }^{* *}-0,30$ & ${ }^{* *} 0,02$ & & \\
\hline $\mathrm{HA}$ & $-0,48^{*}$ & ${ }^{*}-0,75^{*}$ & $-0,08$ & $0,77^{*}$ & *0,05 & $-0,42^{*}$ & ${ }^{* *}-0,26$ & ${ }^{* *}-0,53^{*}$ & ${ }^{*} 0,6$ & ${ }^{* *}$ \\
\hline K & $0,45^{*}$ & * 0,69 * & ${ }^{*} 0,17^{*}$ & $-0,69^{*}$ & $-0,10$ & 0,38 * & ${ }^{* *} 0,34$ & ${ }^{* *} 0,35^{*}$ & ${ }^{*}-0,6$ & $6^{* *}-0,55^{* *}$ \\
\hline
\end{tabular}

*: $p<0,05 ; * *: p<0,01$ EC: Elektriksel İletkenlik; OM: Organik Madde; Hi: Hidrolik Illetkenlik;

HA: Hacim Ağırlığı; K: Așınabilirlilik Faktörü 
Çizelge 6. Jeoistatistiksel yöntemlere ait RMSE değeri

Table 6. RMSE value of the geostatistical methods

\begin{tabular}{llc}
\hline Jeoistatistiksel Modeller & & RMSE \\
\hline \multirow{2}{*}{ Inverse Distance Weighting } & 1 & 0,0285 \\
\multirow{3}{*}{ Radial Basis Functions } & 2 & 0,0289 \\
& 3 & 0,0294 \\
\multirow{2}{*}{ Ordinary Kriging } & Completely Regularized Spline & 0,0293 \\
& Thin Plate Spline & 0,0364 \\
\multirow{2}{*}{ Kriging } & Spherical & 0,0285 \\
& Explenential & 0,0285 \\
& Gaussian & 0,0285 \\
& Spherical & $\mathbf{0 , 0 2 8 4}$ \\
& Exponential & 0,0285 \\
& Gaussian & 0,0286 \\
& Spherical & 0,0285 \\
\hline
\end{tabular}

Çizelge 7. Araștırma alanı așınım sınıflarının alansal ve oransal dağıımı

Table 7. Spatial and proportional distribution of the study area erodibility classes

\begin{tabular}{lccc}
\hline Așınım Sınıfı & Așınım Sınıf Değeri & Alan $\left(\mathrm{km}^{2}\right)$ & Oran (\%) \\
\hline Çok Az Așınabilir & $0-0,05$ & 0,09 & 0.1 \\
Azz Așınabilir & $0,05-0,1$ & 959,41 & 57.8 \\
Orta Derece Așınabilir & $0,1-0,20$ & 696,9 & 42.1 \\
Toplam & & 1656,4 & 100,0 \\
\hline
\end{tabular}

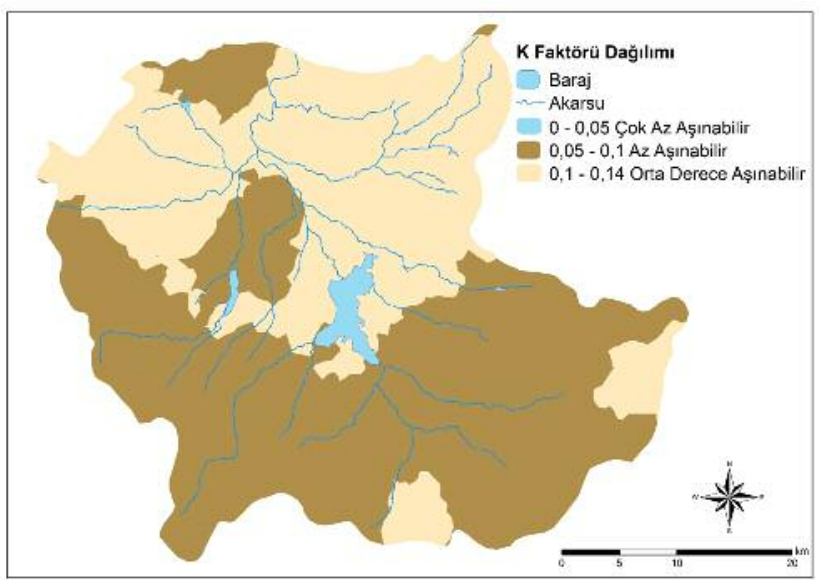

Șekil 5. Araștırma sahası K faktörü dağı̆ım haritası

Figure 5. Distribution map of $K$ factor for the study area

\section{SONUÇLAR}

Bu çalıșmada Çorum Alaca Havzasında dağııııș gösteren toprakların așınabilirlik faktörünün diğer bazı toprak özellikleriyle olan ilișkisi belirlenmiș, ayrıca duyarlılık faktörünün mesafeye bağlı değișkenlik özeliğinin jeoistatistik enterpolasyon yöntem ile dağılım haritası üretilmiștir.
Havza arazilerinin toprak așınabilirlik dağılımına baktığımızda; en düșük $(0,01)$ ve en yüksek $(0,14)$ değerlere göre çok az așınabilir ve orta derece așınabilir değerler gösteren $\mathrm{K}$ faktörünün \% 57,8'inin az așınabilir sınıfına girerken, \% 42, 1 'inin ise orta derece așınabilir sınıfına girdiği belirlenmiștir.

Araștırma sonucunda toprak örneklerine ait K değerinin kil, silt, EC, kireç, organik madde ile arasında istatistiksel açıdan \% 1 düzeyinde önemli pozitif bir ilișki, buna karșın kum, hidrolik iletkenlik ve hacim ağırlığı ile negatif bir korelasyon ilișkisi olduğu bulunmuștur. Araștırma sahası K faktörü dağılım haritası da incelendiğinde kil ve silt miktarının daha fazla olduğu ova seviyesinde eğimin az olduğu sahalarda K değerinin düșük olduğu görülmektedir. Araștırma sahasının güneybatısında bulunan Akçadağ yamaçlarında ise çok az așınabilir sınıfına giren alan yer almaktadır.

\section{KAYNAKLAR}

Auerswald K (1986). Capability of the mapping units of the German government land appraisal for estimating soil erodibility ( $\mathrm{K}$ factor) in Southern Bavaria. Zeitschriftfur Kulturtechnik und Flurbereinigung. 27: 6, 344-351. 
Bașkan O, Dengiz O (2008). Comparison of traditional and geostatistical methods to estimate soil erodibility factor. Arid Land Research and Management. 22 : 29-45.

Blake G R, Hartge K H (1986). Bulk density and particle density. In: methods of soil analysis, part I, physical and mineralogical methods. Pp: 363-381. ASA and SSSA Agronomy Monograph, no:9, (2nd ed), Madison.

Büyüköztürk Ș (2009). Sosyal bilimler için veri analizi el kitabı. Ankara, Pegem Akademi.

Bouyocous G J (1951). A recalibration of the hydrometer method for making mechanical analysis of soils. Agronomy Journal, 43, 435-438.

Balcı N (1996). Toprak Koruması. İstanbul Üniversitesi Yayın No: 3947, Orman Fakültesi Yayın No: 439. s. 490. İstanbul.

Parlak M, Yiğini Y, Ekinci H (2014). Çanakkale Umurbey Ovası Topraklarının Erozyona Duyarlılığının Mevsimsel Değișimi. ÇOMÜ Ziraat Fakültesi Dergisi 2014: 2 (1): 123-131.

Erpul G, Deviren S S (2012). Ülkemizdeki toprak erozyonu sorunu üzerine: ne yapmalı?. Toprak Bilimi ve Bitki Besleme Dergisi, 1(1), Sayfa: 26- 32.

Jackson M L (1958). Soil chemical analysis. Prentice Hall Inc., Englewood Cliffs, N.J.
Karaatlı M (2010). Verilerin düzenlenmesi ve gösterimi, Editör: KalayCl, Ș. SPSS uygulamalı çok değișkenli istatistik teknikleri, Asil Yayın Dağııımı Ltd. Ști Ankara, s. 2-47.

Klute A, Dirksen C (1986). Hydraulic conductivity and diffusivity. In: Klute, A. (Ed), Methods of Soil Analysis. Part 2. Agronomy 9: 687-732. Am. Soc. of Agron., Inc., Madison, Wisconsin, USA.

Renard K G, Foster G R, Weesies G A, McCool D K, Yoder D C (1997). Predicting soil erosion by water: A Guide to Conservation Planning with the Revised Universal Soil Loss Equation (RUSLE). U.S. Department of Agriculture, Agriculture Handbook, 703, Government Printing Office, SSOP, Washington, D.C.

Soil Survey Staff. (1992). Procedures for collecting soil samples and methods of analysis for Soil survey. Soil Surv. Invest. Rep. I. U.S. Gov. Print. Office, Washington D.C. USA.

Soil Survey Staff. (1993). Soil survey manual, USDA. Handbook No: 18 Washington D.C.

Wischmeieri W H, Simith D D (1978). Predicting rainfall erosion losses. USDA Agricultural Handbook, 537, Washington D.C. 